\title{
ミトコンドリアDNAを用いたクロフジツボ類の系統解析
}

\author{
長谷川貴志，山口寿之*，小島茂明,** 太田 秀** \\ *千葉大学理学部地球科学教室, ${ }^{* *}$ 東京大学海洋研究所海洋生物生態部門
}

\section{Phylogenetic Analysis among Three Species of Intertidal Barnacles of the Genus Tetraclita (Cirripedia; Balanomorpha) \\ by Nucleotide Sequences of a Mitochondrial Gene}

\author{
Takashi Hasegawa, Toshiyuki Yamaguchi, Shigeaki Kojima ${ }^{* *}$ and Suguru Ohta ${ }^{* *}$ \\ *Department of Earth Sciences, Chiba University, \\ and ${ }^{* *}$ Ocean Research Institute, University of Tokyo
}

\begin{abstract}
Three species of Tetraclita, T. squamosa, T. formosana and T. japonica, live in the intertidal zone in Japan. The phylogenetic relationships among them (formerly considered as different subspecies of $T$. squamosa) were examined in a previous study of Yamaguchi (1987) based not only on comparisons of morphology and geographic distribution, but also on isozyme electrophoresis. In the present study, their interrelationships are examined using parts of the nucleotide sequences of a mitochondrial gene for cytochome oxidase subunit I (COI). In concordance with the results by isozyme electrophoresis, T. formosana and $T$. japonica are shown to be the closest among the three species. The ancestor of $T$. formosana and T. japonica, themselves being derived recently, diverged earlier from the last common ancestor of the three species.
\end{abstract}

Key words : mt DNA, COI, Tetraclita japonica, Tetraclita squamosa, Tetraclita formosana

はじめに

日本近海には3種の現生クロフジッボ類が生息している. それらはクロフジッボ (T. japonica), タイワンクロフジ ッボ（T. formosana）とミナミクロフジッボ（T. squamosa) で，それらは殼の色以外に特別大きな形態的 差異がなく, クロフジッボ以外は化石標本の確実な同定 が得られていない。

クロフジッボは, 灰色の個体で, 台湾北部から津軽海 峡にかけての外洋および内湾の潮間帯に生息し，3種の中

Received January 12, 1996 : Accepted June 29, 1996
で唯一日本海沿岸にも分布する.タイワンクロフジッボ は, 赤灰色で, 台湾から伊豆半島南岸にかけての外洋に 面した潮間帯に生息している. ミナミクロフジッボは, 緑灰色で, インド洋一太平洋の熱帯から温帯の外洋に面 した潮間帯に分布し, 房総半島南岸が分布域の北限に当 たる.つまり最む広いミナミクロフジッボの分布域の縁 辺部に同所的にタイワンクロフジッボとクロフジッボが 分布している (山口 1986; Yamaguchi 1987).

山口（1986）㧍よびYamaguchi（1987）は, 3種の成体 の形態の比較, リンゴ酸脱水素酵素 (Mdh) の対立遺伝 子頻度の比較を行った. どちらの結果もクロフジッボは, ミナミクロフジッボとよりあタイワンクロフジッボとの 
類似性が高いことを示し，クロフジッボとタイワンクロ フジッボは，3種共通の祖先からミナミクロフジッボが分 化した後, 種分化によって生じたと推論した.

本研究では日本の現生クロフジッボ類3種のミトコンド リアDNA（mt DNA）の塩基配列の比較によって，それ らの類縁関係および種分化過程を明らかにすることを目 的とした。

\section{材料と方法}

\section{材 料}

クロフジッボ類は, 蔓脚類の中でもより派生的形質を あつグループであるフジッボ亜目（Balanomorpha）に 属し, タイワンクロフジッボやミナミクロフジッボの存 在はあまり知られていないが，クロフジッボは日本の潮 間帯中央部に普通に見られる。タイワンクロフジッボ（3 個体使用）およびミナミクロフジッボ（2個体使用）は和 歌山県すさみ町黒崎の海岸で1994年4月25日採集したもの を，ドライアイス中に保存して運搬し，室内実験まで $-80^{\circ} \mathrm{C}$ で冷凍保存した. クロフジッボ（3個体使用）は千 葉県天津小湊町の海岸で1994年3月29日採集したものを, 室内実験まで飼育したものを使用した。

外群としてカメノテ（Capitulum mitella）を1個体用 いた. カメノテは, クロフジッボ類と同じ完胸目 （Thoracica）の異なる亜目，エボシガイ亜目 （Lepadomorpha）に属す, より原始的形質をむつ分類群 である.カメノテはクロフジッボと同じ場所，日時に採 集し，同様に室内実験まで飼育したものを用いた.

\section{分析方法}

冷凍または生きたフジッボの軟組織を緩衝液（0.4M $\mathrm{NaCl}, 125 \mathrm{mM} \mathrm{KCl}, 50 \mathrm{mM}$ Tris (pH8), 0.1M EDTA (pH8））中で細断，遠心分離を繰り返しミトコンドリア を分画した。 そこからフェノールおよびクロロホルムに
より分析用のmtDNAを抽出し，それをエーテルで洗浄， エ夕ノール沈殿を行い，滅菌蒸留水に溶解し $-20^{\circ} \mathrm{C}$ で冷 凍保存した。

次に，抽出したmtDNAのチトクロームオキシダーゼサ ブユニットI（COI）がコードされている領域中約 900 塩 基対の部分をPCR（合成酵素連鎖反応）法で増幅した。 PCRに用いたプライマーは，渡辺・横堀（1993）が後生 動物間で保存的なアミノ酸配列に基づき設計したCOI-3 およびCOI-6と，著者の 1 人が節足動物と環形動物の間で 保存的なアミノ酸配列（小島 未発表）に基づき設計した COI-AおよびCOI-Bの4種類である (Table 1). また, 本研 究では, $94^{\circ} \mathrm{C}$ で1分間保ったあと, 熱変性 $92^{\circ} \mathrm{C} 40$ 秒間, プ ライマーのアニーリング $35^{\circ} \mathrm{C}$ か $50^{\circ} \mathrm{C} 1$ 分間, 複製 $72^{\circ} \mathrm{C}$ 1分から1分30秒間という反応を 30 から40サイクル繰り返 すという条件でPCRを行った，反応終了後，1.5\%アガロー スゲル中でサイズマーカーとともに電気泳動を行い，生 成物の確認をした。

PCR産物は，ミネラルオイルを取り除き，フェノール およびクロロホルム抽出，エタノール沈潵により回収し た. 回収されたPCR産物は, $40 \mu 1$ の滅菌蒸留水に溶解さ せ，塩基配列決定に必要なあの以外は $-20^{\circ} \mathrm{Cで}$ 冷凍保存 した.

塩基配列の決定の準備段階として一本鎖のDNAを得る 方法は，入エキソヌクレアーゼを利用した方法（高木ほ か 1992）を用いた。その後， $\alpha^{32} \mathrm{P}-\mathrm{dATP}$ で標識して Sequenase $^{\circledR}$ Ver.2.0 (U.S.Biochemical社製) を用いて, ジデオキシ法（Sanger et al. 1977）で塩基配列を決定し た。なお一部分, CircumVent ${ }^{\mathrm{TM}}$ Phototope $^{\mathrm{TM}}$ Kit (New England BioLabs ${ }^{\circledR}$ 社製) を用い，サイクルシークエン ス法で決定した配列む含まれている．塩基配列決定に用 いたプライマーは，上述の 4 種類と同一である（Table 1). そして，ショウジョウバエ mtDNA（Clary \& Wolstenholme 1985) およびアルテミア （Valverde et al. 1994）の遺伝暗号にしたがいアミノ酸

Table 1. List of primers used in this study. N, Y, R, S and W represent equal molar mixtures of (G, A, T, C), (T, C), $(G, A),(G, C)$ and $(A, T)$, respectively.

\begin{tabular}{cc}
\hline Name & Sequeuce \\
\hline COI-A & 5'-TCATCTRAANACYTTRAT-3' \\
COI-B & 5'-GGATGAACNGTNTAYCCNCC-3' \\
COI-3 & 5'-GTNTGRGCNCAYCAYATRTTYACNGT-3' \\
COI-6 & 5'-GGRTARTCNSWRTANCGNCGNGGYAT-3' \\
\hline
\end{tabular}


1900

$\begin{array}{ccccccccccccccccccccccc}\text { L } & \text { S } & \text { I } & \text { F } & \text { S } & \text { L } & \text { H } & \text { L } & \text { A } & \text { G } & \text { A } & \text { S } & \text { S } & \text { I } & \text { L } & \text { G } & \text { A } & \text { I } & \text { N } & \text { F } & \text { M }\end{array}$ Tsq TTA TCA ATC TTC TCT CTT CAT CTA GCC GGT GCC TCC TCA ATT CTT GGA GCT ATt AAT TTC ATG $\begin{array}{cccccccccccccccccccccc}\mathrm{Tja} & * * * & * & * & * & * & * & * & * & * & * & * & * & * & * & * & * & * & * & * & * & * \\ & * * & * * * & * * * & * * \mathrm{C} & * * \mathrm{C} & * * * & * * \mathrm{~T} & * * \mathrm{G} & * * \mathrm{~T} & * * \mathrm{~T} & * * \mathrm{C} & * * * & \mathrm{~T} * \mathrm{~A} & * * \mathrm{G} & * * \mathrm{~A} & * * \mathrm{C} & * * * & * * \mathrm{~T} & * * \mathrm{~A}\end{array}$

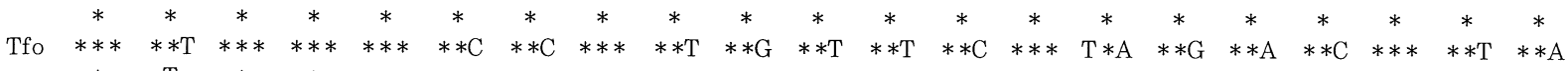
$\begin{array}{ccccccccccccccccccccccc} & * & \mathrm{~T} & * & * & * & * & * & * & * & * & * & * & * & * & * & * & * & * & * & * & * \\ \mathrm{Cmi} & * * * & \mathrm{~A} * \mathrm{C} & * * * & * * * & * * \mathrm{C} & * * * & * * \mathrm{C} & \mathrm{T} * \mathrm{G} & * * \mathrm{~T} & * * \mathrm{G} & * * \mathrm{~T} & * * * & * * \mathrm{~T} & * * * & * * * & * * \mathrm{G} & * * * & * * * & * * * & * * \mathrm{~T} & * * *\end{array}$

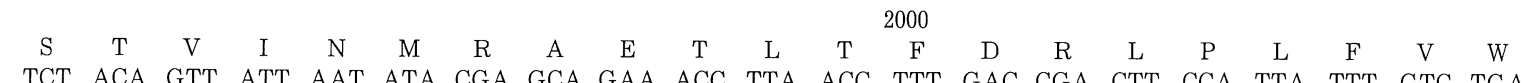
Tsq TCT ACA GTT ATT AAT ATA CGA GCA GAA ACC TTA ACC TTT GAC CGA CTT CCA TTA TTT GTC TGA $\begin{array}{cccccccccccccccccccccc} & * & * & * & * & * & * & * & * & * & * & * & * & * & * & * & * & * & * & * & * & * \\ \mathrm{Tja} & * * \mathrm{~A} & * * * & * * * & * * * & * * \mathrm{C} & * * * & * * * & * * \mathrm{C} & * * * & * * \mathrm{~T} & \mathrm{C} * * & * * \mathrm{~T} & * * * & * * \mathrm{~T} & * * \mathrm{~T} & * * * & * * \mathrm{C} & * * * & * * * & * * \mathrm{~T} & * * *\end{array}$ $\begin{array}{ccccccccccccccccccccc}* & * & * & * & * & * & * & * & * & * & * & * & * & * & * & * & * & * & * & * & *\end{array}$

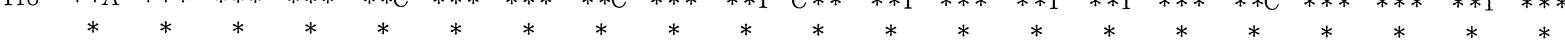

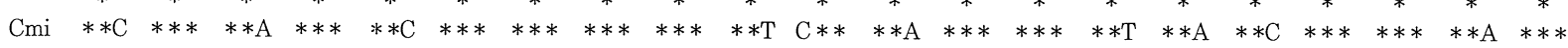

$\begin{array}{cccccccccccccccccccccc} & \text { S } & \text { V } & \text { F } & \text { I } & \text { T } & \text { V } & \text { I } & \text { L } & \text { L } & \text { L } & \text { L } & \text { S } & \text { L } & \text { P } & \text { V } & \text { L } & \text { A } & \text { G } & \text { A } & \text { I } & \text { T } \\ \text { Tsq } & \text { AGT } & \text { GTC } & \text { TTT } & \text { ATT } & \text { ACA } & \text { GTT } & \text { ATT } & \text { CTT } & \text { CTC } & \text { CTC } & \text { CTT } & \text { TCT } & \text { CTT } & \text { CCA } & \text { GTT } & \text { CTG } & \text { GCT } & \text { GGA } & \text { GCT } & \text { ATT } & \text { ACA }\end{array}$ $\begin{array}{cccccccccccccccccccccc} & * & * & * & * & * & * & * & * & * & * & * & * & * & * & * & * & * & * & * & * & * \\ \mathrm{Tja} & * * \mathrm{~A} & * * \mathrm{~T} & * * \mathrm{C} & * * * & * * \mathrm{~T} & * * * & * * * & * * * & * * \mathrm{~T} & * * * & \mathrm{~T} * \mathrm{G} & * * * & * * \mathrm{~A} & * * * & * * * & * * \mathrm{~A} & * * \mathrm{~A} & * * * & * * * & * * \mathrm{C} & * * *\end{array}$

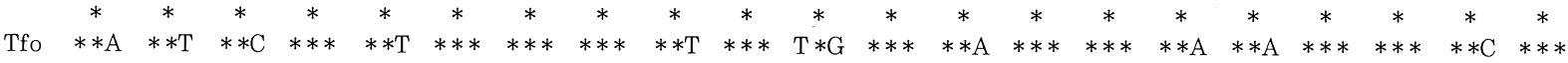

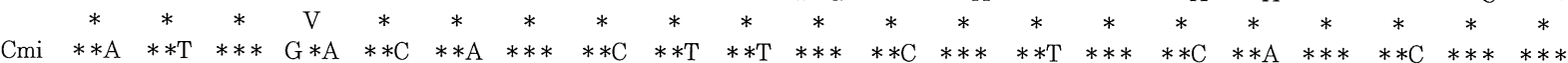

2100

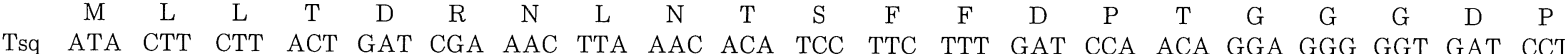
$\begin{array}{cccccccccccccccccccccc} & * & * & * & * & * & * & * & * & * & * & * & * & * & * & * & * & * & * & * & * & * \\ \mathrm{Tja} & * * * & * * \mathrm{C} & \mathrm{T} * \mathrm{G} & * * \mathrm{~A} & * * \mathrm{C} & * * * & * * * & \mathrm{C} * \mathrm{~T} & * * \mathrm{~T} & * * * & * * * & * * * & * * \mathrm{C} & * * \mathrm{C} & * * \mathrm{G} & * * * & * * \mathrm{C} & * * \mathrm{~A} & * * \mathrm{~A} & * * \mathrm{C} & * * \mathrm{C}\end{array}$ $\begin{array}{lllllllllllllllllllll}* & * & * & * & * & * & * & * & * & * & * & * & * & * & * & * & * & * & * & * & *\end{array}$ Tfo $\quad * * * \quad * * \mathrm{C} \quad \mathrm{T} * \mathrm{G} \quad * * \mathrm{~A} \quad * * \mathrm{C} \quad * * * \quad * * * \quad \mathrm{C} * \mathrm{~T} \quad * * \mathrm{~T} \quad * * * \quad * * * \quad * * * \quad * * \mathrm{C} \quad * * \mathrm{C} \quad * * \mathrm{G} \quad * * * \quad * * \mathrm{C} \quad * * \mathrm{~A} \quad * * \mathrm{~A} \quad * * \mathrm{C} \quad * * *$

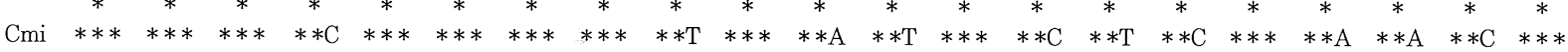
$\begin{array}{cccccccccccccccccccccc} & \mathrm{I} & \mathrm{L} & \mathrm{Y} & \mathrm{Q} & \mathrm{H} & \mathrm{L} & \mathrm{F} & \mathrm{W} & \mathrm{F} & \mathrm{F} & \mathrm{G} & \mathrm{H} & \mathrm{P} & \mathrm{E} & \mathrm{V} & \mathrm{Y} & \mathrm{I} & \mathrm{L} & \mathrm{I} & \mathrm{L} & \mathrm{P} \\ \mathrm{Tsq} & \mathrm{ATT} & \mathrm{CTT} & \mathrm{TAT} & \mathrm{CA} & \mathrm{CAC} & \mathrm{TTA} & \mathrm{TTC} & \mathrm{TGA} & \mathrm{TTC} & \mathrm{TTC} & \mathrm{GGA} & \mathrm{CAC} & \mathrm{CCT} & \mathrm{GAA} & \mathrm{GTC} & \mathrm{TAC} & \mathrm{ATT} & \mathrm{TTA} & \mathrm{ATT} & \mathrm{TTA} & \mathrm{CCA} \\ & * & * & * & * & * & * & * & * & * & * & * & * & * & * & * & * & * & * & * & * & * \\ \mathrm{Tja} & * * * & * * * & * * \mathrm{C} & * * * & * * * & * * * & * * \mathrm{~T} & * * * & * * * & * * \mathrm{~T} & * * \mathrm{~T} & * * * & * * \mathrm{R} & * * * & * * \mathrm{~T} & * * * & * * * & * * * & * * * & \mathrm{C} * \mathrm{~T} & * * * \\ & * & * & * & * & * & * & * & * & * & * & * & * & * & * & * & * & * & * & * & * & * \\ \mathrm{Tfo} & * * * & * * * & * * \mathrm{C} & * * * & * * \mathrm{~T} & * * * & * * \mathrm{~T} & * * * & * * * & * * \mathrm{~T} & * * \mathrm{~T} & * * * & * * \mathrm{G} & * * * & * * \mathrm{~T} & * * * & * * * & * * * & * * * & \mathrm{C} * \mathrm{~T} & * * * \\ & * & * & * & * & * & * & * & * & * & * & * & * & * & * & * & * & * & * & * & * & * \\ \mathrm{Cmi} & * * * & * * * & * * * & * * * & * * * & \mathrm{C} * * & * * \mathrm{~T} & * * * & * * \mathrm{~T} & * * * & * * \mathrm{C} & * * \mathrm{~T} & * * * & * * * & * * * & * * * & * * * & * * * & * * * & \mathrm{C} * \mathrm{~T} & * * \mathrm{~T}\end{array}$ $\begin{array}{lllllllllllllllllllllll}A & F & G & M & I & S & H & I & \text { V } & \text { A } & \text { S } & \text { E } & \text { S } & \text { G } & \text { K } & \text { K } & \text { E } & \text { S } & \text { F } & \text { G } & \text { T }\end{array}$ Tsq GCT TTT GGT ATA ATT TCA CAC ATt GTG GCA AGA GAA AGT GGT AAA AAA GAA TCC TTT GGA ACA

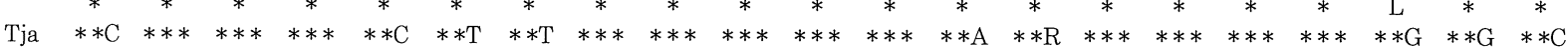
$\begin{array}{cccccccccccccccccccccc} & * & * & * & * & * & * & * & * & * & * & * & * & * & * & * & * & * & * & \mathrm{~L} & * & * \\ \mathrm{Tfo} & * * \mathrm{C} & * * * & * * * & * * * & * * \mathrm{C} & * * \mathrm{~T} & * * \mathrm{~T} & * * * & * * * & * * * & * * * & * * * & * * \mathrm{~A} & * * \mathrm{~A} & * * * & * * * & * * * & * * * & * * \mathrm{G} & * * \mathrm{~A} & * * \mathrm{C}\end{array}$ $\begin{array}{cccccccccccccccccccccc} & * & * & * & * & * & * & * & * & * & * & * & * & * & * & * & * & * & * & * & * & * \\ \mathrm{Cmi} & * * * & * * \mathrm{C} & * * \mathrm{C} & * * \mathrm{G} & * * * & * * * & * * \mathrm{~T} & * * * & * * \mathrm{~T} & * * \mathrm{C} & * * * & * * * & * * \mathrm{~A} & * * * & * * * & * * * & * * * & * * \mathrm{~A} & * * * & * * * & * * \mathrm{~T}\end{array}$

2300

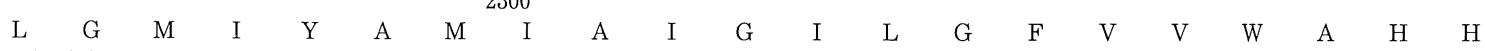
Tsq TTA GGA ATA ATT TAC GCA ATA ATC GCA ATT GGA ATC TTA GGA TTt GTA GTC TGA GCC CAC CAC $\begin{array}{cccccccccccccccccccccc} & * & * & * & * & * & * & * & * & * & * & * & * & * & * & * & * & * & * & * & * & * \\ \mathrm{Tja} & * * * & * * \mathrm{C} & * * \mathrm{G} & * * * & * * * & * * * & * * * & * * * & * * \mathrm{~T} & * * * & * * * & * * \mathrm{~T} & \mathrm{C} * \mathrm{~T} & * * \mathrm{~T} & * * * & * * * & * * \mathrm{~A} & * * * & * * \mathrm{G} & * * * & * * *\end{array}$

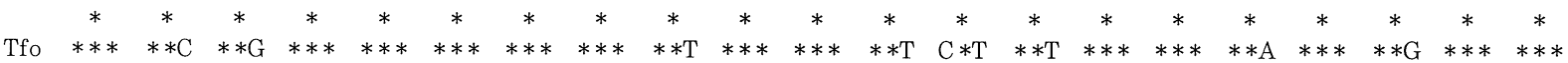
$\begin{array}{cccccccccccccccccccccc} & * & * & * & * & * & * & \mathrm{I} & * & * & * & * & * & * & * & * & * & * & * & * & * & * \\ \mathrm{Cmi} & \mathrm{C} * * & * * * & * * * & * * * & * * \mathrm{~T} & * * \mathrm{C} & * * \mathrm{~T} & * * * & * * * & * * * & * * * & * * \mathrm{~T} & \mathrm{C} * * & * * * & * * \mathrm{C} & * * \mathrm{~T} & * * \mathrm{~A} & * * * & * * \mathrm{~T} & * * * & * * *\end{array}$

Fig. 1. Nucleotide and deduced amino acid sequences of part of COI gene for Tetraclita squamosa \# (Tsq), Tetraclita japonica\# (Tja), Tetraclita formosana \# (Tfo) and Capitulum mitella \# (Cmi). Identity to T. squamosa is indicated by an asterisk. Question marks represent missing data. Nucleotides at intraspecific polymorphic sites indicated by R(A or G) or $\mathrm{Y}(\mathrm{C}$ or $\mathrm{T})$. Attached numbers above sequences correspond to the position of the homologous nucleotide in Drosophila yakuba (Clary \& Wolstenholm 1985). 
$\begin{array}{llllllllllllllllllllllllllll}M & \mathrm{~F} & \mathrm{~T} & \mathrm{~V} & \mathrm{G} & \mathrm{M} & \mathrm{D} & \mathrm{V} & \mathrm{D} & \mathrm{T} & \mathrm{R} & \mathrm{A} & \mathrm{Y} & \mathrm{F} & \mathrm{T} & \mathrm{S} & \mathrm{A} & \mathrm{T} & \mathrm{M} & \mathrm{I} & \mathrm{I}\end{array}$ Tsq ATG TTC ACA GTA GGT ATA GAC GTT GAT ACT CGA GCT TAC TTT ACA TCC GCT ACT ATA ATT ATC

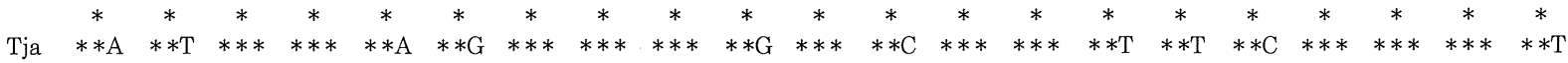

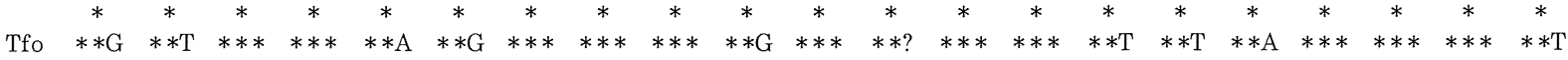
$\begin{array}{cccccccccccccccccccccc} & * & * & * & * & * & * & * & * & * & * & * & * & * & * & * & * & * & * & * & * & * \\ \mathrm{Cmi} & * * \mathrm{~A} & * * \mathrm{~T} & * * \mathrm{~T} & * * * & * * \mathrm{~A} & * * \mathrm{G} & * * \mathrm{~T} & * * \mathrm{G} & * * * & * * * & * * \mathrm{~T} & * * \mathrm{C} & * * * & * * * & * * \mathrm{~T} & * * \mathrm{~A} & * * * & * * * & * * * & * * * & * * \mathrm{~T}\end{array}$ $\begin{array}{llllllllllllllllllllllllll}A & \text { V } & P & T & G & \text { I } & \text { K } & \text { V } & \text { F } & \text { S } & \text { W } & \text { L } & \text { G } & \text { T } & \text { L } & \text { H } & \text { G } & \text { S } & \text { Q } & \text { F } & \text { S }\end{array}$ Tsq GCG GTC CCA ACC GGG ATT AAA GTA TTC AGT TGA CTA GGA ACA CTC CAT GGC TCT CAA TTC TCC

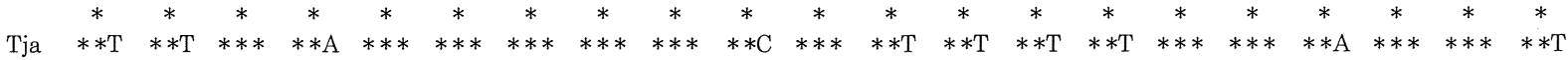
$* \quad * \quad * \quad * \quad * \quad * \quad * \quad * \quad * \quad * \quad * \quad * \quad * \begin{array}{llllllllllll}* & * & * & * & * & * & * & * & * & * & *\end{array}$ Tfo $* * \mathrm{~T} \quad * * \mathrm{~T} \quad * * * \quad * * \mathrm{~A} \quad * * * \quad * * * \quad * * * \quad * * * \quad * * * \quad * * \mathrm{C} \quad * * * \quad * * \mathrm{~T} \quad * * \mathrm{~T} \quad * * \mathrm{~T} \quad * * \mathrm{~T} \quad * * * \quad * * * \quad * * \mathrm{~A} \quad * * * \quad * * * \quad * * \mathrm{Y}$ $\begin{array}{cccccccccccccccccccccccccccccccccccc}\mathrm{Cmi} & ? * \mathrm{~A} & * * \mathrm{~A} & * * \mathrm{~T} & * * * & * * \mathrm{~T} & * * * & * * * & * * * & * * * & * * * & * * * & \mathrm{~T} * * & * * * & * * * & * * \mathrm{~A} & * * * & * * * & \mathrm{~A} * \mathrm{C} & * * * & * * * & * * \mathrm{~T}\end{array}$

2500

$\begin{array}{llllllllllllllllllllllllllllllllllll}\mathrm{Y} & \mathrm{S} & \mathrm{P} & \mathrm{P} & \mathrm{L} & \mathrm{L} & \mathrm{W} & \mathrm{A} & \mathrm{L} & \mathrm{G} & \mathrm{F} & \mathrm{L} & \mathrm{F} & \mathrm{L} & \mathrm{F} & \mathrm{T} & \mathrm{V} & \mathrm{G} & \mathrm{G} & \mathrm{V} & \mathrm{T}\end{array}$ Tsq TAC AGT CCT CCT CTC CTC TGA GCT CTT GGG TTT CTC TTC TTA TTT ACA GTT GGG GGA GTA ACA

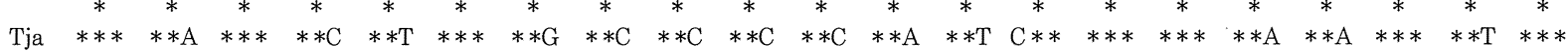

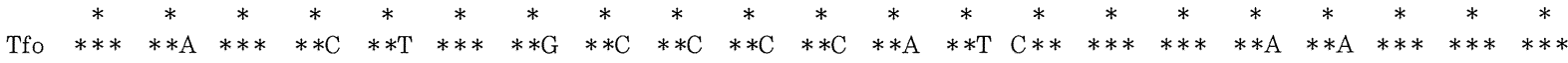

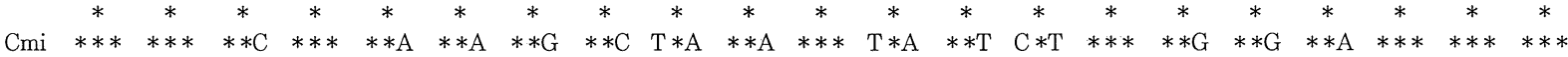

$\begin{array}{lllllllllllllllllllllllll}\mathrm{G} & \mathrm{V} & \mathrm{V} & \mathrm{L} & \mathrm{A} & \mathrm{N} & \mathrm{S} & \mathrm{S} & \mathrm{L} & \mathrm{D} & \mathrm{I} & \mathrm{V} & \mathrm{L} & \mathrm{H} & \mathrm{D} & \mathrm{T} & \mathrm{Y} & \mathrm{Y} & \mathrm{V} & \mathrm{V} & \mathrm{A}\end{array}$ Tsq GGA GTA GTA CTA GCG AAT TCA TCT TTA GAC ATC GTC TTA CAC GAT ACC TAC TAT GTA GTA GCC

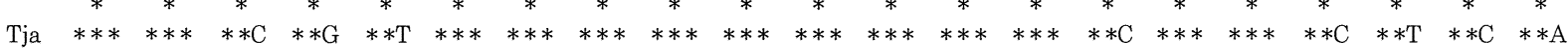

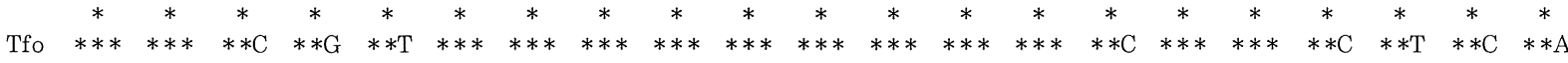

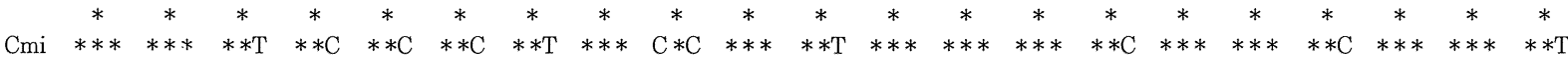

$\begin{array}{rrllllllllllllllllllllllll} & 2600 \\ \mathrm{H} & \mathrm{F} & \mathrm{H} & \mathrm{Y} & \mathrm{V} & \mathrm{L} & \mathrm{S} & \mathrm{M} & \mathrm{G} & \mathrm{A} & \mathrm{V} & \mathrm{F} & \mathrm{G} & \mathrm{I} & \mathrm{M} & \mathrm{A} & \mathrm{G} & \mathrm{A} & \mathrm{V} & \mathrm{Y} & \mathrm{W}\end{array}$ Tsq CAC TTC CAC TAC GTC CTT TCT ATA GGA GCA GTA TTt GGC ATC ATA GCA GGA GCA GTt TAC TGA $\begin{array}{cccccccccccccccccccccc} & * & * & * & * & * & * & * & * & * & * & * & * & * & * & * & * & * & * & * & * & * \\ \mathrm{Tja} & * * \mathrm{~T} & * * * & * * \mathrm{~T} & * * * & * * \mathrm{~T} & * * * & * * \mathrm{C} & * * * & * * * & * * \mathrm{~T} & * * * & * * \mathrm{C} & * * \mathrm{~A} & * * \mathrm{~T} & * * * & * * * & * * \mathrm{G} & * * * & * * * & * * * & * * \mathrm{G}\end{array}$

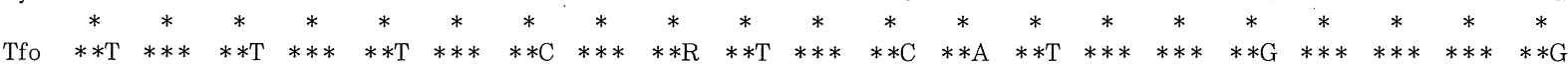

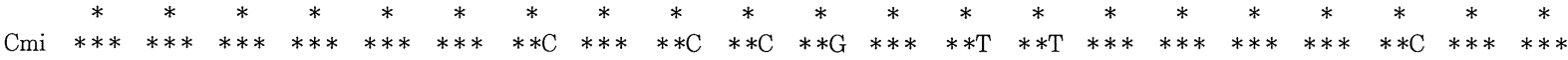

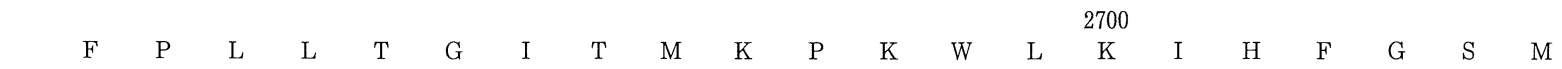
Tsq TTC CCC CTT CTT ACA GGT ATT ACT ATA AAA CCT AAA TGA TTA AAA ATT CAT TTC GGT TCC ATA $\begin{array}{cccccccccccccccccccccc} & * & * & * & * & * & * & * & * & * & * & * & * & * & * & * & * & * & * & * & \mathrm{~A} & * \\ \mathrm{Tja} & * * \mathrm{~T} & * * \mathrm{~T} & * * \mathrm{C} & * * * & * * \mathrm{~T} & * * * & * * * & * * \mathrm{C} & * * * & * * * & * * \mathrm{C} & * * \mathrm{G} & * * * & \mathrm{C} * * & * * * & * * \mathrm{C} & * * \mathrm{C} & * * \mathrm{~T} & * * \mathrm{~A} & \mathrm{G} * \mathrm{~T} & * * *\end{array}$ $* \begin{array}{lllllllllllllllllllll}* & * & * & * & * & * & * & * & * & * & * & * & * & * & * & * & * & * & * & \mathrm{~A} & *\end{array}$

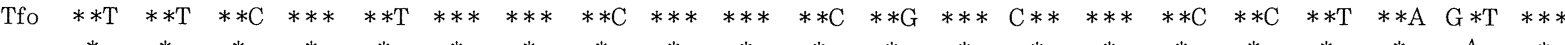

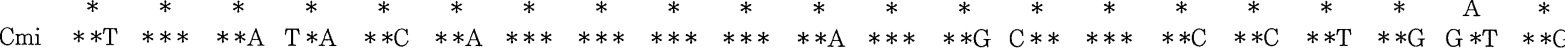

$\begin{array}{ccccc}\text { Tsq } & \text { TTC } & \text { G } & \text { G } & \text { V } \\ \text { TTA } & \text { GGA } & \text { GTT }\end{array}$

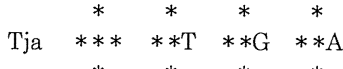

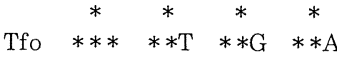

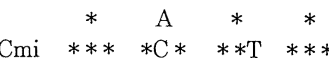

Fig. 1. (continued) 
配列を推定した。

塩基座位当たりの置換数は, Kimura（1980）の2変数 法により計算した。また，系統樹は近隣結合法， UPGMA，および最大節約法の3つの方法で作成した。こ れらの解析には, コンピュータソフトMEGA Version 1.01 (Kumer et al. 1993) を使用した.

\section{結果および考察}

\section{塩基配列の比較}

クロフジッボ類 3 種は連続する約 830 塩基，カメノテは 一部Van Syoc（1994）および長谷川（未公表資料）より 引用し，同様に連続する約830塩基について比較を試みた (Fig. 1).クロフジッボ類3種では, ミナミクロフジッボ 対クロフジッボおよびタイワンクロフジッボの間に，そ れぞれ147個および144個と比較的多くの塩基置換が観察 される.しかし，アミノ酸配列を比較すると，277個のア ミノ酸座位のうち, 置換が起きているのは2座位にすぎな
い.すなわち，生じた塩基置換のほとんどはアミノ酸の 置換を伴わない同義的置換であった。このように3種間の アミノ酸置換が少ないことは，3種間が従来考えられてい たように比較的近縁な関係にあることを示唆するあの之 考えられる.

一方, クロフジッボ類の中であクロフジッボとタイワ

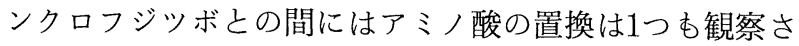
れない. 塩基置換のすべてが，コドンの第3座位に生じた 同義的置換である. しかも, その個数はこれら2種とミナ ミクロフジッボとの間の置換数と比べると, 著しく少な い.

なお，クロフジッボとタイワンクロフジッボには，同 種個体間でそれぞれ2個および3個の塩基の差異が存在し た。それらはすべて, コドンの第3座位に生じた転位（ト ランジション）型の置換である。クロフジッボとタイワ ンクロフジッボとの種間には最大で 13 個の塩基の差異が あり，その中には2個の転換（トランスバージョン）型の 置換も含まれている.したがって, 置換数と置換型の両

Table 2. Genetic distances in the upper-right matrix and standard errors in the lower-left matrix computed by Kimura's 2-parameter method(Kimura 1980).

\begin{tabular}{lcccc}
\hline & T. japonica & T. formosana & T. squamosa & C. mitella \\
\hline T. japonica & & 0.0122 & 0.2034 & 0.2194 \\
T. formosana & 0.0039 & & 0.2000 & 0.2178 \\
T. squamosa & 0.0178 & 0.0176 & & 0.2024 \\
C. mitella & 0.0184 & 0.0183 & 0.0176 & \\
\hline
\end{tabular}

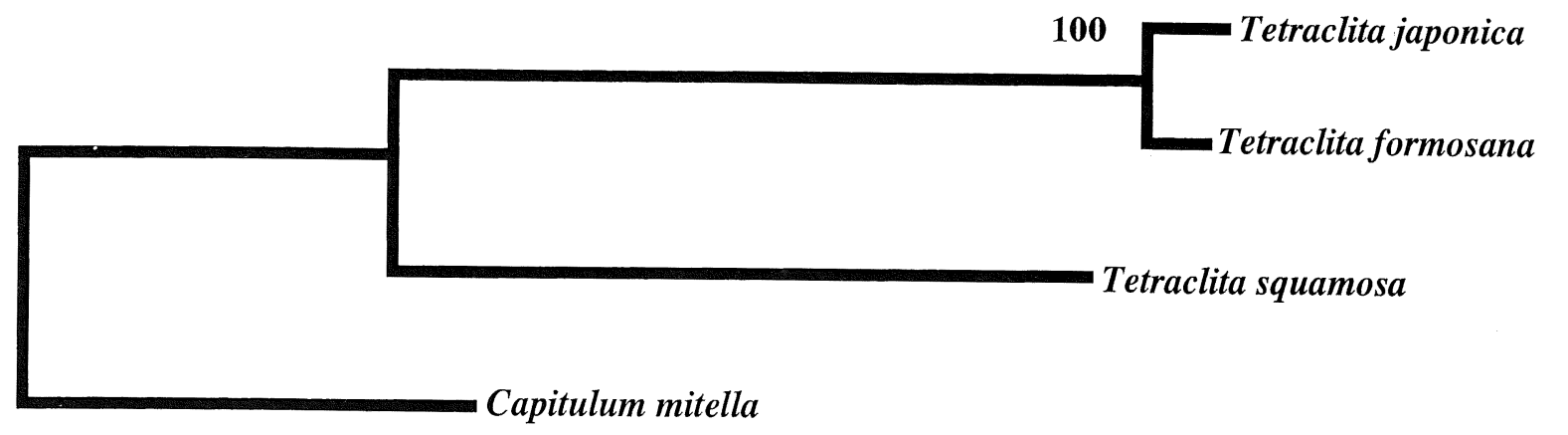

approximately equal to the genetic distance of 0.01

Fig. 2. A phylogenetic tree for 3 species of tetraclitids and a goose barnacle as an outgroup, constructed by the neighbor joining method. 
方に関して，これら2種について種間の変異が種内の変異 を上回っているといえる.

\section{系統関係}

まず，塩基配列デー夕をもとに，祖先種の塩基配列か ら最少の置換数で得られる系統樹を選択するという最大 節約法（Fitch 1971）で解析を行った。なお，カメノテ は比較のための外群である.その結果得られた系統樹は, クロフジッボが，ミナミクロフジッボとよりも，夕イワ ンクロフジッボとより近縁であることを示している.

Table 2は, Kimura（1980）の2变数法により計算され た, 各種間の座位当たりの塩基置換数, すなわち遺伝距 離と, その標準誤差を示している。この遺伝距離をもと にしたUPGMA（Sokal \& Michener 1958）とFig.2に示 す近隣結合法（Saitou＆Nei 1987）による系統樹は,最 大節約法による系統樹と同じ樹形を示した。この系統樹 の信頼性を調べるため，ブーツストラップ法 （Felsenstein 1985）で検定を行った. 多くの場合，ブー ッストラップ確率が70以上であれば，95\%以上の確率で， その部分の系統関係が正しいことが知られている（Hillis \& Bull 1993).ここでは500回の計算を行い，クロフジッ ボとタイワンクロフジッボの分岐に関して 100 という值が 得られた。 また，UPGMA と近隣結合法の両方で同じ樹 形が得られれば，その結果はかなり信用できるという (根井 1990).

以上のことから，日本沿岸に生息するクロフジッボ類 は，3種共通の祖先からまずミナミクロフジッボが分化し， 次にタイワンクロフジッボとクロフジッボとが分化した と結論でき，それは統計的にも支持される．山口（1986） およびYamaguchi（1987）は，3種のクロフジッボ類の地 理的分布から，クロフジッボとタイワンクロフジッボは ミナミクロフジッボの分布の周辺での地理的隔離によっ て生じたと解釈した。本研究で得られた結果は，この予 想と対立するものではない. 現在, 他の 2 種に比べて非常 に広い分布域をむつミナミクロフジッボが，地質時代の 比較的初期から存在し, 最近になってその分布の周辺で 種分化が生じて, クロフジッボとタイワンクロフジッボ が派生したと考えられる。

\section{謝 辞}

カメノテの塩基配列はカリフォルニア科学アカデミー のR.J.Van Syoc博士から贈られた学位論文の資料を使っ た。また実験および資料解析にあたっては，東京大学海 洋研究所海洋生物生態部門, 千葉大学理学部地球科学教
室地史学・古生物学教育研究グループおよび自然科学研 究科環境科学専攻環境基礎科学講座地殼進化学講座のみ なさんから貴重な意見をいただいた，以上の方々に感謝 申し上げる。

また，この研究の一部に科学研究費・一般研究（A） (代表山口寿之 (No.06404001)), 国際学術研究（学術調 査）（代表池谷仙之（No.06041045)），および総合研究 （A）（代表棚部一成（No.07304042））を使用した.

\section{引用文献}

Clary, D. O. and D. R. Wolstenholme 1985 The mitochondrial DNA molecule of Drosophila yakuba: Nucleotide sequence, gene organization, and genetic code. Journal of Molecular Evolution, 22: 252-271.

Felsenstein, J. 1985 Confidence limits on phylogenies: An approach using the bootstrap. Evolution, 39: 783-791.

Fitch, W.M. 1971 Toward defining the course of evolution: Minimum change for a specific tree topology. Systematic Zoology, 20: 406-416.

Hillis, D.M. and J.J. Bull 1993 An empirical test of bootstrapping as a method for assessing confidence in phylogenetic analysis. Systematic Biology, 42: 182-192.

Kimura, M. 1980 A simple method for estimating evolutionary rates of base substitutions through comparative studies of nucleotide sequences. Journal of Molecular Evolution, 16: 111-120.

Kumar, S., K. Tamura and M. Nei 1993 MEGA:Molecular Evolutionary Genetics Analysis, Version 1.01. Institute of Molecular Evolutionary Genetics, The Pennsylvania State University, University Park, Pennsylvania. 130pp. 根井正利 1990 分子進化遺伝学, 五條堀孝・斎藤成也 (共訳), 培 風館, 東京. $433 \mathrm{pp}$.

Saitou, N. and M. Nei 1987 The neighbor-joining method: A new method for reconstructing phylogenetic trees. Molecular Biology and Evolution, 4: 406-425.

Sanger, F., S. Nicklen and A.R. Coulson 1977 DNA sequencing with chain-terminating inhibitors. Proceedings of the National Academy of Sciences of the United States of America, 74: 5463-5467.

Sokal, R.R. and C.D. Michener 1958 A statistical method for evaluating systematic relationships. University of Kansas Science Bulletin, 28: 1409-1438.

高木茂・木村穣・勝木元也 $1992 \lambda$ エキソヌクレアーゼを利用 したPCR産物の直接塩基配列決定法. 蛋白質 核酸 酵素, 37: 868-873.

Valverde, J.R., B. Batuecas, C. Moratilla, R. Marco and R. Garesse 1994 The complete mitochondrial DNA sequence of the crustacean Artemia franciscana. Journal of Molecular Evolution, 39: 400-408. 
Van Syoc, R.J. 1994 Molecular Phylogenetics and Population Structure Derived from Mitochondrial DNA Sequence Variation in the Edible Goose Barnacle Genus Pollicipes (Cirripedia, Crustacea). Ph.D. dissertation, University of California, San Diego, 60pp.

山口寿之 1986 日本のクロフジッボ類の地理的分布および種間 関係. 日本ベントス研究会誌, 29: 25-36.

Yamaguchi, T. 1987 Changes in the barnacle fauna since the Miocene and the infraspecific structure of Tetraclita in Japan (Cirripedia; Balanomorpha). Bulletin of $M a-$ rine Science, 41: 337-350.

渡辺公綱・横堀伸一 1993 ミトコンドリア遺伝子の進化. 分子進 化実験法, 日本生化学会 (編), 東京化学同人, 東京, pp.241259.
連絡先

山口寿之 (別刷請求先), 長谷川貴志: 千葉大学理学部地球科学 教室, 干263 千葉市稲毛区弥生町1-33

小島茂明，太田 秀: 東京大学海洋研究所海洋生物生態部門, ₹164 東京都中野区南台1-15-1

Address

Toshiyuki Yamaguchi (reprint request), Takashi Hasegawa : Department of Earth Sciences, Chiba University, 1-33 Yayoi-cho, Inage, Chiba 263, Japan

Shigeaki Kojima, Suguru Ohta : Ocean Research Institute, University of Tokyo, 1-15-1 Minamidai, Nakano, Tokyo 164, Japan 